\title{
Legal Certainly of Land Registration towards Sustainable National Development
}

\author{
Elita Rahmi
}

\begin{abstract}
There are 2 (two) Research Problems, namely: First How to register land that can improve land registration services in Jambi Province through a program of complete. Second How can the technology used so that land registration in Indonesia can be accelerated to reach one hundred percent (126 million new registered land parcels) 51 million have not registered 75 million parcels of land) to realize sustainable development in Indonesia. The research method used is empirical juridical with a sampling system that is purposive sampling with the land registration hypothesis that the government must do in fact still reaches 68 percent, so there needs to be an acceleration of technology that can increase the rate of measurement and mapping of existing land. Conclusion. The technology system Land registration in Jambi province with a coordinate system apparently still causes a lot of land disputes in Indonesia, so that there needs to be a more integrated system and integrated team that can minimize uncertainty in land measurement and mapping, so that it can maximize taxation and national, provincial and regency / city spatial planning. Both integrated land registration technologies, by involving relevant institutions as stipulated in Presidential Instruction No. 2 of 2018 concerning the Acceleration of Land Registration and community participation, and officials at the village level and determining points and digitizing land maps will be able to minimize land conflicts and disputes as well as multiple certificates that have been occurring so far, thus harming the State and society, due to the exhaustion of time, energy due to the weakness of the existing land registration system. Increasing the quantity and quality of land registration will accelerate the realization of sustainable development as a conscious and planned effort that can integrate environmental aspects, national social and economic aspects for the welfare of previous generations, present and future generations.
\end{abstract}

Keywords: Legal certainty, Land Registration.

\section{BACKGROUND}

The issue of land registration in Indonesia is characterized by uncertainty about the subject, objek, and the status of land rights, as a result of the system used in land registration, it is possible for a person or legal entity to commit an unlawful act in form, falsify procedures, falsify physical data on the location, boundaries and extent of land and legal.

cases of conflicts and land disputes, such as: double certificates, land area that coincides with other people's land due to the resolution of certificates, separation and land merging, changes in land data due to court decisions, and measurement techniques that are still manual coordinate systems that are still local, so that changes in shape land due to disasters and summer climate change and flooding, resulting in land being lost or arising, as well as changes in regional expansion and expansion of villages, sub-districts, districts / cities and provinces, so that almost every region we encounter is a conflict area (Gaza) not finished $(1,2)$.

Weak coordination between technical agencies makes land registration only limited to obtaining land certificates, not yet at the stage of achieving sustainable development that leads to economic acceleration and the safety of future generations, so that cases of biological children sue their parents for family property, and the case of a child who sues a grant or inheritance to a fellow child heir, shows that land issues must be integrated, because land is a dimension of the past, present and future (3).

The age of land registration in Indonesia has reached 58 (fifty eight) years. Since the enactment of Law Number 10 of 1961 concerning Land Registration and renewed with PP No. 24 of 1997 concerning land registration, it means that almost half a century Indonesia has implemented Article 19 UUPA regarding registration issues. land, but only around 68 percent (51 million) of which around 75 million have been carried out are still not registered, out of the existing 126 million land, if this registration does not yet use advanced technology, it will take around 100 years to complete existing land registration.

Slowing down land registration efforts can certainly increase conflict and disputes, instead accelerating land registration will realize sustainable development in the field of land resources, for which sustainable development as a philosophical foundation in consideration of Government Regulation Number 24 of 1997 concerning Land Registration is a legal ideal need to be immediately followed up in the national land law order, especially in orderly land registration services in Indonesia $(4,5)$.

Sustainable development in the field of land registration is closely related to legal certainty for sustainable development Goals (SDGs) which later changed to the Millennium Development Goals / MDGs. Where land registration is a legal and institutional key word to ensure 17 Goals, 169 targets and 240 indicators can be found the right steps for the State, both the central and regional governments in social, economic, environmental and inclusive aspects (6). 


\section{RESEARCH PROBLEMS}

Based on the background above, then there are 2 (two) problems in the study of the Legal Certainty of Land Registration in Jambi Province Towards Increasing Sustainable National Development, namely.

First What is the land registration model using the Complete Systematic Land Registration Program that can improve land registration services in Jambi Province, so that the purpose of land registration for legal certainty and legal protection of subjects, objects and land status is protected.

Second What is the relationship between land registration and sustainable development, so that the transfer of land rights can be controlled and not become a dispute for future generations, but instead becomes a sustainable business capital for future generations. And increasing economic and social rights and even culture and land and family security in the future, on the other hand the government needs to carry out comprehensive and integrated technology, so that land registration in Indonesia can be accelerated to reach one hundred percent (126 million land parcels) registered to reach 51 million have not registered 75 million plots of land) to realize sustainable development in Indonesia.

\section{Research Purposes}

The purpose of this study is 2 (two) Objectives, namely:

The First Research Objective is: To find out the land registration model in Jambi Province which consists of 10 Regencies and 1 City. This data is needed to find out the quantity numbers from the description of land registration in Jambi Province. This data is needed to measure the maximum percentage that can be done by the Jambi Provincial Land Agency in encouraging registration of land parcels that have been utilized by the community to provide legal certainty on land rights that are used by the community for their survival. As well as to test the research hypothesis that the land registration rate in Jambi is still low compared to other provinces.

Second Research Objective: To measure whether sustainable development as a philosophical foundation of land registration stated in the consideration of PP No. 24 of 1999 concerning land registration has become the principle in conducting land registration in Jambi Province. Continuous development in land registration means that the registered land can be used as the basic capital for children or future generations for the land subject, or the land is transferred in the form of being sold to other parties, so that in the end the children or grandchildren become laborers on their own land. Passive land registration will impact sustainable development in the form of high numbers poverty and the slow rate of growth in community welfare in Jambi province.

\section{RESEARCH METHODS}

This type of research is an exploratory sociological study with an evaluative form of research, because this study aims to measure the performance of the Jambi Province Land Agency, particularly in the field of land registration which is responsible for the process of land registration in Jambi Province in this case the Head of Land Office in each Regency / City in Jambi Province. Legal research is not only a principle and norm / norm, but also a social phenomenon. By using the legal concept put forward by Mochtar Kusumaatmadja that law is the whole principle and rules governing human life in society, including institutions and processes that realize these rules in reality. Thus this research is based on 2 (two) hypotheses by looking at the gap between das sein and das sollen, prioritizing secondary legal data and materials and further strengthened by primary legal materials that occur in society, especially in Jambi Province, with the research approach used is a legal approach, conceptual approach, and case approach.

The research method used is juridical empiric with a sampling system that is purposive sampling with the land registration hypothesis that must be carried out by the government in fact still very low, so there needs to be an acceleration effort that can increase the rate of measurement and mapping of existing land. realizing sustainable development namely increasing legal certainty, guaranteeing legal protection and community welfare, because land certificates can be used as collateral to the Bank as venture capital.

\section{RESEARCH RESULT}

\section{A. Land Registration in Jambi Province}

To carry out the land registration of the National Land Agency, the technical implementation was actually carried out by the Head of the Land Office assisted by the Land Deed Making Officer, as well as other officials assigned to be able to help share certain activities.

Regional Office of the National Land Agency of Jambi Province, covering the Jambi City Land Office, Batanghari District Land Office, Bungo Regency Land Office, Sarolangun District Land Office, Kerinci Regency Land Office, Tanjung Jabung Barat Land Office and Tebo Regency Land Office, Merangin Regency Office, Office Land of Tanjung Jabung Timur Regency, Muaro Jambi Regency Land Office.

The Land Office above is an organ that is technically working in ensuring the subject, object and status of the subject and object (status of land rights), with the Object of Land Registration, are as follows:

- Land ownership, business use rights, building use rights and use rights

- Land Management Right

- Land of Endowments

- Ownership of Unit Flats

- Dependent Rights

- State Land

Based on Article 1 number 1 of Government Regulation Number 24 of 1999 concerning Land Registration, elements of land registration, namely: 
- There is a series of registration activities

- The activity is under the authority of the government

- The nature of activities is continuous and continuous

- Regularly

- In addition to the plot of land also covers apartment units

- Giving proof of rights

- There are certain rights that burden him

The above elements of land registration cannot be separated from the principle of land registration, namely:

- A simple principle, namely land registration can be understood and understood by all parties

- Safe Principle, which is carried out very carefully and very carefully, so that it can guarantee legal certainty

- Affordable Principle, services that are affordable by those who need and pay attention to the weak economic group

- Final Principle, adequate equipment is available in the process of land registration and data maintenance, also up-to-date, and recording changes that occur in the future

- The principle is open, everyone can get the correct data or information.

Based on the elements of land registration and principle and the purpose of the land registration, since 2017 the Jambi Province BPN has handed over 11,393 plots of land to the people of Jambi Province. The government target is 40 thousand and 2018 is targeted at 70 thousand. On the other hand, one of the regencies in Jambi Province, namely in 2018, the Kerinci Land Agency ranks first from 11 regencies / cities in Jambi Province, because of the 10,000 systematic land registration certificates. (PTSL) Kerinci Land Office actually managed to complete 10200 certificates or 102 percent.

The performance of the Kerinci Land Office implies that there is a high increase in the performance of the Land Agency in the Jambi Province

In line with the agrarian reform program and efforts to minimize the imbalance of tenure structures, ownership and including land use, empowering the community to utilize land assets and strengthen community rights to land

Land registration in Jambi province. In order to curb the administration of land registration, a very futuristic policy was established in the acceleration process namely the Complete Systematic Land Registration Program using the latest technology in line with the service modernization system in the ATR / BPN ministry. Integrated single submission services for location permit services, land technical considerations, detailed spatial planning and zoning information.

Based on the above facts, since 2018 the performance of the Land office in Jambi Province has experienced a significant increase in land registration services, due to the Presidential Instruction in the Government Nawacita Program which requires the Land Office to implement measurable targets nationally based on existing land parcels. Land registration services are carried out through the district / city Land Office which includes, measuring, mapping and accounting for land.

\section{B. Complete Systematic Land Registration Program as an Example for Accelerating Land Registration}

The Complete Systematic Land Registration Program (PTSL) is a step forward in accelerating land registration in Indonesia, the program requires synergies between the Central and Regional Governments including the business community and the community, so the PTSL program can be a model of renewal in the land registration system in Indonesia, even if the program This is still dominated by BPN in the form of land registration process, but the program has opened our eyes that the issue of land registration is not solely on legal certainty, but can also solve the issue of justice and benefit of the law, namely the process of saving past generations, present and which will come.

President's Instruction Number 2 of 2018 concerning the Acceleration of Complete Systematic Land Registration throughout Indonesia. Stipulated on February 13, 2018 in Jakarta is a movement aimed at the realization of complete land registration for the entire territory of the Republic of Indonesia to support the National Strategic Project.

The Complete Systematic Land Acceleration Performance classifies 3 Clusters, namely the registration of land throughout Indonesia:

- Land Division that meets the requirements for issuance of land certificates

- Land parcels which are only recorded in the land register, because they have not fulfilled the requirements for issuing land certificates, because the land is in dispute or is in the process of being litigated in court

- Land parcels which are only registered in the land register, because they have not fulfilled the requirements for issuance of certificates, because the subject and object of the land have not fulfilled the requirements to be granted rights to land registration activities, because they are unknown.

Programs that make / prepare / revise regulations governing the period of announcement of physical data and juridical data to speed up the completion of complete systematic land registration and conduct evaluation and monitoring and report on the implementation of instructions periodically to the President.

This acceleration is important and determines the overall performance of the government, even though only about 14 (fourteen) agencies are expressly obliged to work in a comprehensive manner, but there is still a need for space for public awareness to properly inform physical and juridical data to the government. .

As for the duties and functions, the Minister of Environment in question is:

Providing spatial data on the boundaries of forest areas in all regions of Indonesia to the Ministry of Agrarian and Spatial Planning / BPN in areas bordering the forest by giving approval to boundary signatories take steps to settle with the Ministry of Agrarian and Spatial Planning / $\mathrm{BPN}$ in favor of the use,

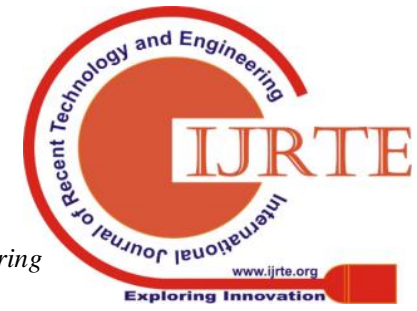


use, control and ownership of community land within the forest area.

- Minister of Public Works and Housing provides information about the spatial data on the boundaries of rivers, lakes / reservoirs / Embung boundaries to the Minister of Agrarian and Spatial Planning / BPN and provides assistance to physical data and juridical data collectors.

Minister of Home Affairs to facilitate the Governor / Regent / Mayor in taking steps

- The Minister of BUMN encourages SOEs to participate through the Social and Environmental Responsibility (CSR) budget by taking into account Good Corporate Governance.

Assistance to officers of physical data and juridical data that borders on BUMN land by participating in giving approval to sign boundaries

- The Minister of Finance may provide a fiscal policy to the burden of the public on Stamp Duty and Income Tax

- The Village Minister, Underdeveloped Regional Development and Transmigration provides data on the location of transmigration

- The Chief of Police prioritizes the administrative process through Law Number 30 Year 2014 concerning Government Administration before conducting investigations into public reports

Coordination among the ministers above is key to the success of the Systematic Acceleration of land registration program in Indonesia.

Other ministers who are both preventive and comprehensive in the context of synergy between one business and another are interesting to collaborate through the president as the executive holder in Indonesia.

\section{As an assistant to the Land Office in Land Registration}

The existence of an unknown Land Deed Officer in Law Number 5 Year 1960 concerning Basic Agrarian Basic Regulations or popular designation But in the development of government needs for land registration, it provides space for the form of "deed" to be the choice of the agreement that intends to move land rights, mortgaging land or lending money with land rights as dependents of deed evidence before officials appointed by the Head of the National Land Agenc . the birth of PPAT through Government Regulations that did not embed the profession as a noble profession, in the end led to a long debate in the academic world, considering PPAT, in terms of regulation, deeds issued and status as assistants of the Land Office, often out of the concept of deed determined in Law Number 2 Year 2014 concerning Notary Position. In the development of the national legal system (Notary Law, civil law, state administrative law, land registration law, as well as the philosophy of law / professional ethics, investment law). The existence of the deed issued by the Land Deed Making Officer (PPAT) received serious attention namely doubting the validity of the PPAT deed as an authentic deed, (overlapping functions of the notary and PPAT functions in the land sector) and the legal basis of PPAT only in the form of Government Regulations and PPAT institutions' functions. banji "(not a professional organization and does not have an honor council, even though PPAT duties are very vulnerable to ethics / morals). which aims as an organ of certainty in land registration law in Indonesia, thus the role of PPAT has an important and strategic meaning in national development and efforts to realize land justice (economic social and cultural rights of people to live in their own country), so that welfare and social justice become real existence. Becoming all of our homework to think that land registration is something that is in line with the national legal system, and the existence of PPAT (7).

The position of the Land Deed Maker Officer (PPAT) becomes very interesting, if we recall the 74 years of independent Indonesia (August 17, 1945-17 August 2019), and 59 years of age in the LoGA (September 24, 1960-24 September 2019, LNRI 1960 No 104. TLNRI No 2043), 56 years of land registration age (Government Regulation Number 10 of 1961, replaced with Government Regulation Number 24 of 1997 concerning land registration) 21 years of age of PPAT (PP 37 of 1998 concerning Position Regulations Officer of Land Deed, March 5, 1998. National Republic of Indonesia Year 1998 Number 52. TLN Number 3736 and Government Regulation Number 24 Year 2016 concerning Amendments to Government Regulation Number 37 of 1998). This means 74 years of Indonesian age, 59 years of age of LoGA, 56 years of land registration and 19 years of PPAT age in Indonesia. That is, the legal certainty of land registration is still utopian $(8,9)$.

Portrait of "many people do not have land and few people control a lot of land", the poverty gap continues to widen, and conflicts, land disputes continue to occur. Rohing's case in Myanmar is related to poverty and the struggle for natural resources, correcting our thoughts. That if the government neglects to uphold the issue of agrarian resources including land, then the fourth aspiration of the opening of the 1945 Constitution and mandate of Article 33 of the 1945 Constitution that the State regulates control over the earth water and natural resources for the greatest prosperity of the people in order to create a just and prosperous society will be far from expectations, as well as the ideals of the UUPA so that the state is responsible for creating a just nature based on divinity, humanity, unity, wise people in deliberations that realize the meaning of local wisdom aka customary law to realize social justice for all Indonesian people.

The authority above is unfortunately determined in a limited manner by the Minister in this case BPN, thus the PPAT function is no more than filling in the bills issued by the BPN, so PPAT does not need to deeply understand the principles of the deed as stipulated in the UUJN. According to Salim PPAT, it cannot freely develop the substance stated in the PPAT form in accordance with the professional land register insights and capabilities, this is due to the substance stated in the PPAT deed formalized by the government, and if the PPAT makes the PPAT deed requested by the parties incompatible with the form and procedure for filling out which is stipulated in agrarian policy number 8 of 2012 , the

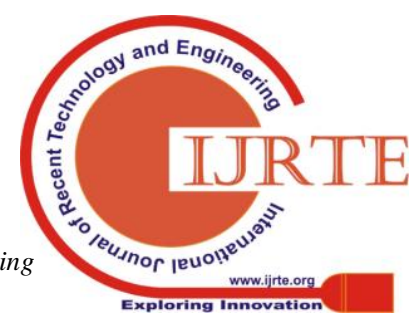


Land office will reject the registration of the deed made by the PPAT (11).

The relationship between PPAT and BPN is a unified whole, so professional land register is appointed and dismissed by BPN, through the appointment of professional land register given the authority to make certain legal deeds regarding land rights or ownership rights to apartment units, such as sale and purchase deeds, exchange, grants, income in the company's capital) inbreng), sharing rights together, imposing mortgage rights.

The position of Professional land register in land registration is an official in this case is the official of the land deed, so that conceptually the official referred to in the corridor of article 19 of the Land of regulasi (Letters of proof of rights), regulasi government No. 24 of 1997 concerning land registration is an official, but on the other hand the legal form of acta products is a deed in this case is a professional land register deed as evidence of certain legal deeds, regarding land rights or ownership rights to apartment units for the basis of registration or change registration data caused by a legal act.

\section{Certificate as a Facility Towards Sustainable National Development}

In Environmental Laws Continuous development means conscious and planned efforts that integrate environmental, social and economic aspects into development strategies to ensure the integrity of the environment and the safety, capability and welfare and quality of life of present and future generations. Based on the concept then the land certificate as proof of rights is a conscious effort for the government and planned through a national strategic acceleration program that correlates with socio-economic development in this case is a certificate as a valuable letter that can be a guarantee as a form of business capital.

Certificate as a valuable letter and Proof of Land Rights, management rights, waqf land, Property Rights to housing units and mortgage rights that have been recorded in the relevant land book. Based on the value letter, this land certificate is often the community, inter-family conflict, due to differences in views about inheritance, distribution of joint assets or other causes, so that cases of children suing their biological mothers related to joint assets, and grants and endowments parents unknown or doubtful or sued by par heirs, or even denied by his child, proving that there is a land group that cannot be known to the subject of the land, making a big record in land registration in Indonesia.

\section{CONCLUSION}

- Land registration and sustainable development in Jambi Province have not yet synergized and have not collaborated, thus the legal act of land registration is still one goal as a realization of legal certainty and has not yet led to a multi-function, namely land registration will be enjoyed by future generations of subjects of land rights, Socialization of the functions and benefits of land registration is needed which can realize social justice and the salvation of future generations. increasing quantity of land registration in Jambi province, correlated with the addition of business capital to the community, so that people's welfare can be realized. BPN is an institution that is given the authority to register land and other institutions that follow up on land use programs, local and central government must be controlled continuously and continuously.

- Land registration at the Land Office is not only to guarantee legal certainty but also for family welfare and future generations, so that it can become the basic capital for the community to make land certificates as business capital in order to improve the welfare of the community, For that National Land Registerand Professional land register and Bank and government technical agencies in the field of Agriculture, Cooperatives are a unified whole to synergize land as an effort to improve the function of land known as land reform. The success of the Transmigration program in Jambi (Transmigration in Kuamang Kuning), Transmigration at Rimbo Bujang, reaching 738,961 of 3,092,265 residents of Jambi. Synergy between National Land Register and stakeholders is important in an effort to improve the quantity and quality of land registration in Indonesia.

\section{REFERENCE}

[1] Harsono B. Hukum Agraria Indonesia.Himpunan Peraturan-Peraturan Hukum Tanah, Edisi 2007. Jakarta: Djambatan; 2007.

[2] Chomzah AA. Hukum Agraria (Pertanahan Indonesia). Jakarta: Prestasi Pustaka; 2004.

[3] Rahmi E. Hukum Pertanahan dalam Sistem Hukum Indonesia. Bandung: Unpad Press; 2011.

[4] Parlindungan AP. Pendaftaran Tanah di Indonesia Berdasarkan PP 24 Tahun 1997 dilengkapi dengan Peraturan Jabatan Pembuat Akta Tanah PP 37 Tahun 1998. Bandung: Mandar Maju; 1999.

[5] Supriyadi BE. Hukum Agraria Kehutanan Aspek Hukum Pertanahan Dalam Pengelolaan Hutan Negara. Jakarta: Raja Grafindo; 2013.

[6] Pramudianto A. Hukum Lingkungan Internasional. Rajawali; 2017.

[7] Habib Adjie. Hukum Notaris Indonesia Tafsir Tematik Terhadap UU No.30 Tahun 2004 Tentang Jabatan Notaris. Bandung: Refika Aditama; 2009.

[8] Hermit H. Cara Memperoleh Sertipikat Tanah Hak Milik, Tanah Negara Dan Tanah Pemda, Teori dan Praktek Pendaftaran Tanah di Indonesia. Bandung: Mandar Maju; 2004.

[9] Maria, Sumardjono. Kebijakan Pertanahan. Jakarta: Buku Kompas; 2007.

[10] Friedman FLM. Sistem Hukum Perspektif Ilmu Sosial (The Legal System A Sosial Science Perspective). Bandung: Nusamedia; 2009.

[11] Salim. Teknik Pembuatan Akta Pejabat Pembuat Akta Tanah (PPAT). Jakarta: Raja Grafindo Persada; 2016.

[12] Sidharta. Etika dan Kode Etik Profesi Hukum. Bandung: Refika Aditama; 2006.

\section{AUTHORS PROFILE}

my name is Rahmi, currently working as Lecturer at the Faculty of Law, Jambi University Campus Jambi University. A.Manap Street.Telanaipura Jambi Sumatera Indonesia.my area of interest is sustainable development . 